- e ISSN-0976-6855 | Visit us : www.researchjournal.co.in

\title{
Detection of pink bollworm, Pectinophora gossypiella, Saunders infestation using Soft X-ray machine
}

\author{
S. NANDINI* AND S. MOHAN ${ }^{1}$ \\ Fertilizer Control Laboratory, TIRUVARUR (T.N.) INDIA \\ ${ }^{1}$ School of Post Graduate Studies, Tamil Nadu Agricultural University, COIMBATORE (T.N.) INDIA
}

\section{ARITCLE INFO}

Received : 28.04 .2015

Revised : 01.08 .2015

Accepted : 16.08 .2015

\section{KEY WORDS :}

Pink bollworm, Infestation, X-ray, Non destructing sampling
*Corresponding author: Email: nandhunannu@gmail.com

\begin{abstract}
An experiment was carried on standardization of X-ray radiography methodology for the detection of pink bollworm infestation in cotton bolls during 2012-14 at Indian Institute of Crop Processing Technology, Thanjavur, Tamil Nadu, India. Studies revealed that the controllable input electrical parameters of the X-ray machine viz., voltage, current and exposure period required for the detection of internal infestation varied widely for cotton bolls compared to stored grains and fruits tested by other scientists. High voltage and current were required for dense cotton bolls to ensure adequate penetration of radiation. It was observed on visual analysis that the $\mathrm{X}$-ray radiation generated at $80 \mathrm{kV}$ and $10 \mathrm{~mA}$ for 30 seconds resulted in the best visual images to view internal content of cotton bolls and observed to be the best for cotton bolls imagery out of 96 combinations tested for best detection of hidden infestation. While other combinations, for example, $60 \mathrm{Kv}, 4 \mathrm{~mA}$ for 10 seconds and $90 \mathrm{Kv}, 10 \mathrm{~mA}$ for 30 seconds manifested into lighter and darker images, respectively.
\end{abstract}

How to view point the article : Nandini, S. and Mohan, S. (2015). Detection of pink bollworm, Pectinophora gossypiella, Saunders infestation using Soft X-ray machine. Internat. J. Plant Protec., 8(2) : 256-260. 